\title{
Brain Aromatase Modulates Serotonergic Neuron by Regulating Serotonin Levels in Zebrafish Embryos and Larvae
}

\author{
Zulvikar Syambani Ulhaq and Mitsuyo Kishida* \\ Graduate School of Science and Technology, Kumamoto University, Kumamoto, Japan
}

\section{OPEN ACCESS}

Edited by:

Takayoshi Ubuka, Monash University

Malaysia, Malaysia

Reviewed by:

Gustavo M. Somoza,

Instituto de Investigaciones

Biotecnológicas (IIB-INTECH),

Argentina

José A. Muñoz-Cueto,

University of Cádiz, Spain

*Correspondence: Mitsuyo Kishida mkishida@gpo.kumamoto-u.ac.jp

Specialty section: This article was submitted to Neuroendocrine Science, a section of the journa Frontiers in Endocrinology

Received: 23 February 2018 Accepted: 23 April 2018

Published: 09 May 2018

Citation:

Ulhaq ZS and Kishida M (2018) Brain Aromatase Modulates Serotonergic Neuron by Regulating Serotonin Levels in Zebrafish Embryos and Larvae. Front. Endocrinol. 9:230. doi: 10.3389/fendo.2018.00230
Teleost fish are known to express two isoforms of P450 aromatase, a key enzyme for estrogen synthesis. One of the isoforms, brain aromatase (AroB), cyp19a1b, is highly expressed during early development of zebrafish, thereby suggesting its role in brain development. On the other hand, early development of serotonergic neuron, one of the major monoamine neurons, is considered to play an important role in neurogenesis. Therefore, in this study, we investigated the role of AroB in development of serotonergic neuron by testing the effects of (1) estradiol $\left(E_{2}\right)$ exposure and (2) morpholino (MO)mediated AroB knockdown. When embryos were exposed to $E_{2}$, the effects were biphasic. The low dose of $\mathrm{E}_{2}(0.005 \mu \mathrm{M})$ significantly increased serotonin $(5-\mathrm{HT})$ positive area at 48 hour post-fertilization (hpf) detected by immunohistochemistry and relative mRNA levels of tryptophan hydroxylase isoforms (tph1a, tph1b, and tph2) at $96 \mathrm{hpf}$ measured by semi-quantitative PCR. To test the effects on serotonin transmission, heart rate and thigmotaxis, an indicator of anxiety, were analyzed. The low dose also significantly increased heart rate at $48 \mathrm{hpf}$ and decreased thigmotaxis. The high dose of $\mathrm{E}_{2}(1 \mu \mathrm{M})$ exhibited opposite effects in all parameters. The effects of both low and high doses were reversed by addition of estrogen receptor (ER) blocker, ICI 182,780, thereby suggesting that the effects were mediated through ER. When AroB MO was injected to fertilized eggs, 5-HT-positive area was significantly decreased, while the significant decrease in relative tph mRNA levels was found only with tph2 but not with two other isoforms. AroB MO also decreased heart rate and increased thigmotaxis. All the effects were rescued by co-injection with AroB mRNA and by exposure to $E_{2}$. Taken together, this study demonstrates the role of brain aromatase in development of serotonergic neuron in zebrafish embryos and larvae, implying that brain-formed estrogen is an important factor to sustain early development of serotonergic neuron.

Keywords: estradiol, brain aromatase, biphasic manner, serotonergic neuron, zebrafish, early development

\section{INTRODUCTION}

Biosynthesis of estrogen is catalyzed by the action of cytochrome P450 aromatase, a product of cyp19a1 gene $(1,2)$. Contrary to mammals, zebrafish and many other teleosts have two isoforms of aromatase gene, cyp19a1a and cyp19a1b, encoding ovarian and brain aromatase, respectively $(3,4)$, and their predominant expression in respective tissues indicates differential regulation and 
functions. Fish brain is characterized by having much higher aromatase expression in brain compared to mammals (5). At the same time, fish brain has been reported to exhibit elevated neuroregenerative capacity compared to mammals (6-8). Widespread proliferation zones are detected in zebrafish brain $(6,9)$, while only limited areas such as subependymal and subgranular zones exhibit proliferation in mammals (7). Such high neurogenic activity in teleost fish may be attributed to increased synthesis of estrogen due to the elevated expression of brain aromatase. Indeed, expression of brain aromatase is localized in radial glial cells (RGCs), which differentiate into neurons and other glial cells contributing to adult neurogenesis as well as developmental neurogenesis (10-12). Developmental studies in zebrafish show that expression of brain aromatase in embryos increases rapidly after 12 hour post-fertilization (hpf), and is regulated by positive feedback loop through its own product, estrogen, acting on estrogen response element of $c y p 19 a 1 b(3,13,14)$. Therefore, the zebrafish model expressing elevated levels of brain aromatase in early development is suitable to investigate the functional significance of aromatase and neural estrogen in developing brain.

Serotonin (5-HT), a neurotransmitter produced by multiple enzymatic steps including a rate-limiting action of tryptophan hydroxylase (TPH), plays a major role in a number of physiological processes and pathological conditions, such as depression $(15,16)$, stress $(15,17)$, cardiac function (18), reward seeking behavior (19), and anxiety $(15,20)$. In addition, serotonergic neuron is known to be involved in neurogenic activities (21). It has been reported that 5 -HT is critically involved in the brain plasticity, neural trafficking, synapse formation, and network construction during development $(22,23)$. Serotonergic neurons in raphe nuclei extend their axons to the forebrain possibly modulating the differentiation of neuronal progenitors (24). Early ontogeny of serotonergic system may further suggest its role in brain development (25). Raphe 5-HT populations in human brain are considered as the earliest to be identified $(24,26)$.

Serotonergic neurons in mammalian brain are localized mainly in raphe nuclei of brain stem, which project into accumbens, hypothalamus, substantia nigra, and periaqueductal gray $(22,23)$. On the other hand, 5-HT-positive cell bodies are detected mainly in three populations in adult fish brain: pretectal area, posterior tuberculum/hypothalamus, and raphe $(27,28)$. Interestingly, distributions of serotonergic populations and their fibers overlap with highly proliferative areas of fish brain, which may indicate serotonergic regulation in adult neurogenesis in fish (27). In adult zebrafish, serotonin has been shown to promote regeneration of motor neurons by acting on progenitor cells (29).

It is well documented that serotonergic neuron is one of the targets of estrogen in mammals $(30,31)$. In macaques, estrogen increases gene expression and protein contents for TPH (32), and decreases gene expression of the serotonin reuptake transporter and the 5HT1A autoreceptor $(33,34)$. In mammals, both $\mathrm{ER} \alpha$ and $\mathrm{ER} \beta$ are expressed in 5-HT neurons with differential distributions depending on species and sex (35-37). ER $\beta$ has been shown to regulate $t p h 2$ expression in serotonergic neurons $(38,39)$. Similarly in teleost fish, effects of ovarian steroids on serotonin system have been reported in some species. In tilapia, the response of 5 - $\mathrm{HT}$ content in brain to $\mathrm{E}_{2}$ treatment was dependent on developmental stages. Treatment between days 7 and 10 posthatching decreased $5-\mathrm{HT}$ content, while the treatment at later stages increased it (40). Similar result was obtained in Japanese sea bass, which shows a significant decrease in brain 5-HT content in fingerlings after $\mathrm{E}_{2}$ treatment, while the content increased in juvenile group (41). Indeed, overlapping distributions of ER with raphe 5-HT innervation in telencephalon and diencephalon of adult zebrafish brain implies close association of ER and serotonergic neurons $(27,42)$. It has been reported that ER $\beta$ exhibits broad distribution along the brain ventricles of telencephalon and diencephalon in adult zebrafish (43), though co-localization of ER in serotonergic neurons has yet to be documented in fish.

Therefore, in this study, we tested the hypothesis that brain aromatase modulates serotonergic neuron in early development of zebrafish. In order to elucidate a possible role of brain-formed estrogen, we first examined the effects of exogenous $E_{2}$ and then MO-mediated knockdown of brain aromatase on parameters such as 5 -HT contents, relative tph expression levels, heart rate, and thigmotaxis in zebrafish embryos and larvae.

\section{MATERIALS AND METHODS}

\section{Fish Maintenance and Embryo Culture}

Adult zebrafish (Danio rerio) were obtained from the local pet shop and reared in a 60-L tank. Water temperature was maintained at $26-30^{\circ} \mathrm{C}$, and the light regime was $14 \mathrm{~h}$ of light starting at 10:00 followed by $10 \mathrm{~h}$ of dark. Fish were fed with TetraMin (Tetra Japan Inc.) twice a day. Fertilized eggs were collected within 15 min after fertilization and washed in embryo medium (EM) $\left(0.004 \% \mathrm{CaCl}_{2}\right.$, $0.163 \% \mathrm{MgSO}_{4}, 0.1 \% \mathrm{NaCl}$, and $0.003 \% \mathrm{KCl}$ ) to remove debris. Embryos were transferred to a 6 -well plastic plate (30 embryos in $8 \mathrm{~mL}$ of EM per well), and incubated at $28 \pm 0.5^{\circ} \mathrm{C}$. The medium was changed daily. All experimental procedures and maintenance of fish were conducted in accordance with the Guide for Care and Use of Laboratory Animals published by the US National Institutes of Health.

\section{Exposure Experiments}

Stock solutions of $17 \beta$-estradiol $\left(\mathrm{E}_{2}\right)$ (Sigma-Aldrich) at $10 \mathrm{mM}$, ICI 182,780 (ICI) (Tocris Bioscience) at $10 \mathrm{mM}$, and dexamethasone (DEX) (Wako) at $100 \mathrm{mM}$ were prepared in dimethyl sulfoxide (DMSO), and diluted with EM to the final concentrations indicated in the experiments. Quipazine maleate salt (Q) (Sigma-Aldrich) and fluoxetine hydrochloride (FLX) (Wako) were dissolved in ethanol at 100 and $10 \mathrm{mM}$, respectively, which were further diluted with EM to the final concentrations used in the experiments. Control embryos were cultured in $0.1 \%$ DMSO or ethanol. Exposure started at $2 \mathrm{hpf}$ and continued till embryos and larvae were subjected to the assays. The media were changed daily.

\section{Morpholino (MO) Microinjection}

Morpholino antisense oligos were purchased from Gene Tool. MO sequences are shown in Table 1. MOs were dissolved in distilled water to $50 \mathrm{mg} / \mathrm{mL}$ and stored at $-20^{\circ} \mathrm{C}$. Before injection, 
MO solution was heated at $65^{\circ} \mathrm{C}$ for $5 \mathrm{~min}$ and further diluted to the working concentrations $(2.5$ and $5 \mathrm{ng} / \mathrm{nL})$ with deionized $\mathrm{H}_{2} \mathrm{O}$ containing rhodamine $\mathrm{B}$ (Wako). The final concentration of rhodamine $\mathrm{B}$ was $0.08 \%$. MO was injected into embryos at one to four cell stages using a glass microcapillary injection needle attached to the automatic nanoliter injector (Drummond Scientific). Injection volume was set at $2.3 \mathrm{~nL}$ per embryo. After the injection, embryos were observed under the fluorescence microscope (Leica M165 FC), and embryos that did not exhibit red fluorescence were discarded. To examine the effect of MO-mediated AroB knockdown, AroB MO designed to block translation was injected (2.5 and $5 \mathrm{ng} / \mathrm{nL})$. Uninjected embryos (C), embryos injected with $5 \mathrm{ng} / \mathrm{nL}$ of standard control $\mathrm{MO}$ (Std MO), and inverted AroB MO (InvB MO) served as control groups. MO to block translation of cyp19a1a, ovarian aromatase (AroA MO) was also tested for 5-HT immunohistochemistry. As

TABLE 1 | Morpholino (MO) sequences.

\begin{tabular}{llc}
\hline Name & Sequence & Reference \\
\hline $\begin{array}{l}\text { AroA MO (ovarian } \\
\text { aromatase MO) }\end{array}$ & GGAGCAGATCACCTGCCATAAGAAC & This paper \\
Genebank Acc. No:: & & \\
AF226620 & & \\
\hline $\begin{array}{l}\text { InvA MO (inverted } \\
\text { ovarian aromatase MO) }\end{array}$ & CAAGAATACCGTCCACTAGACGAGG & This paper \\
\hline $\begin{array}{l}\text { AroB MO (brain } \\
\text { aromatase MO) }\end{array}$ & ATCCTTACCACATGCTCCATCATC & This paper \\
$\begin{array}{l}\text { Genebank Acc. No.: } \\
\text { AF226619 }\end{array}$ & \\
\hline $\begin{array}{l}\text { InvB MO (inverted } \\
\text { brain aromatase MO) }\end{array}$ & CTACTACCTCGTACACCATTCCTA & This paper \\
\hline $\begin{array}{l}\text { Std MO (standard } \\
\text { control MO) }\end{array}$ & CCTCTTACCTCAGTTACAATTATA & Gene tools \\
\hline $\begin{array}{l}\text { p53 MO } \\
\text { Genebank Acc. No.: }\end{array}$ & & \\
NM 131327 & GCGCCATTGCTTGCAAGAATTG & (44, 45) \\
\hline
\end{tabular}

it has been reported that MO injection will cause off-target effect such as apoptosis through activation of $p 53$ gene $(44,45), \mathrm{MO}$ to block translation of p53 (p53 MO) at $2 \mathrm{ng} / \mathrm{nL}$ was co-injected with AroB MO at $5 \mathrm{ng} / \mathrm{nL}$.

For rescue experiments, the AroB mRNA (30 pg/nL) was coinjected with AroB MO (5 ng/nL). The full length AroB cDNA was obtained by One Step PrimeScript RT-PCR Kit (Takara) using total RNA from 7-dpf zebrafish larvae and AroB primers (Table 2). Amplified products were purified with NucleoSpin Gel and PCR Clean-up (Machery-Nagel) and subcloned into pGEM-T Easy Vector (Promega). Nucleotide sequences and orientation of the inserts were verified by DNA sequencing analysis carried out using BigDye Terminator v3.1 Cycle Sequencing Kit (Applied Biosystems) and ABI 3130 xl genetic analyzer (Applied Biosystems). Plasmid DNA was linearized with SalI and the full length AroB mRNA was transcribed in vitro by MAXIscript T7 Kit (Ambion).

\section{Western Blot and Dot Blot Analysis}

The antiserum to brain aromatase was produced in a rabbit against the synthetic peptide, CNSNGETADNRTSKE of zebrafish AroB (Sigma-Genosys). This peptide sequence has been used to raise the specific antibody as previously described (47). To confirm the specificity of the antiserum, Western blot of brain extract was conducted. Adult female zebrafish were exposed to $\mathrm{E}_{2}$ ( 5 and $25 \mathrm{ng} / \mathrm{L}$ ) or vehicle alone (0.00025\% DMSO) for $24 \mathrm{~h}$ (three fish per group). Brains were pooled and homogenized in HBST buffer (100 mM NaCl, 10 mM HEPES, 0.5\% Triton-X 100, 0.01\% TPCK, and $0.01 \%$ TLCK). After centrifugation at $10,000 \mathrm{~g}$ for $10 \mathrm{~min}$, protein concentrations in supernatant were measured using BCA protein assay kit (Thermo Scientific). Extracts ( $30 \mu \mathrm{g}$ protein/ sample) were separated on $12.5 \%$ SDS-PAGE and transferred to a PVDF membrane. Precision Plus Protein Unstained Standards (Bio-Rad) were used for size reference. After blocking by $1 \%$ skim milk in PBS for $1 \mathrm{~h}$, the membrane was incubated with the AroB antiserum (1:500) for $2 \mathrm{~h}$, and then with the secondary antibody

TABLE 2 | PCR primers and conditions.

\begin{tabular}{|c|c|c|c|}
\hline Gene & Primer sequence $\left(5^{\prime} \rightarrow 3^{\prime}\right)$ & Size of PCR product (bp) & Amplification profile \\
\hline \multirow[t]{3}{*}{$\operatorname{tph1a}$} & F: TTCAAGGACAATGTCTATCG & 214 & $94^{\circ} \mathrm{C}-30 \mathrm{~s}$ \\
\hline & R: GGGAGTCGCAGTGTITGATG & & $55^{\circ} \mathrm{C}-30 \mathrm{~s}$ \\
\hline & Genebank Acc. No.: AF548566 (46) & & $72^{\circ} \mathrm{C}-60 \mathrm{~s}$ (35 cycles) \\
\hline \multirow[t]{3}{*}{$\operatorname{tph} 1 b$} & F: TACCTGCAGAACCTGCCTCT & 430 & $94^{\circ} \mathrm{C}-30 \mathrm{~s}$ \\
\hline & R: AGAGAAGACCAGCCCCGTAT & & $55^{\circ} \mathrm{C}-30 \mathrm{~s}$ \\
\hline & Genebank Acc. No.: BC154120 (46) & & $72^{\circ} \mathrm{C}-60 \mathrm{~s}$ (35 cycles) \\
\hline \multirow[t]{3}{*}{ tph2 } & F: GTGTGAACTCCAAAGCAGCA & 684 & $94^{\circ} \mathrm{C}-30 \mathrm{~s}$ \\
\hline & R: TGGTATTCCTTCCCCATCTG & & $55^{\circ} \mathrm{C}-30 \mathrm{~s}$ \\
\hline & Genebank Acc. No.: AB125219 (46) & & $72^{\circ} \mathrm{C}-60 \mathrm{~s}$ (35 cycles) \\
\hline \multirow[t]{4}{*}{ cyp19a1b (AroB) } & F: TTAAAGAGGTGTGTCTGTATGTGAGGTG & 1,435 & $42^{\circ} \mathrm{C}-10 \mathrm{~min}$ \\
\hline & R: GGAATITACTCTGTGCGCCTITAAATGT & & $94^{\circ} \mathrm{C}-30 \mathrm{~s}$ \\
\hline & Genebank Acc. No: BC076104 & & $60^{\circ} \mathrm{C}-15 \mathrm{~s}$ \\
\hline & & & $72^{\circ} \mathrm{C}-90 \mathrm{~s}$ (40 cycles) \\
\hline \multirow[t]{3}{*}{$\beta$-Actin } & F: GGTATGGGACAGAAAGACAG & 330 & $94^{\circ} \mathrm{C}-30 \mathrm{~s}$ \\
\hline & R: AGAGTCCATCACGATACCAG & & $58^{\circ} \mathrm{C}-30 \mathrm{~s}$ \\
\hline & Genebank Acc. No: AF025305 (3) & & $72^{\circ} \mathrm{C}-60 \mathrm{~s}$ (34 cycles) \\
\hline
\end{tabular}


conjugated with alkaline phosphatase (AP) (Abcam) (1:1,000) for $1 \mathrm{~h}$. After washing, the membrane was incubated in AP buffer (0.1 M Tris-HCl, $\mathrm{pH}$ 9.5, 0.1 M NaCl, $1 \mathrm{M} \mathrm{MgCl}$ ) for $1 \mathrm{~min}$. Signals were developed for 2-3 min in BCIP/NBT substrate (Roche) diluted at 1:50 in AP buffer, and the reaction was stopped by $0.5 \mathrm{M}$ EDTA. All the incubation steps were done at RT. The antiserum to ovarian aromatase was raised in a rabbit using a synthetic peptide, CKPDVYFRLDWLHKKHKRD of zebrafish AroA (Sigma-Genosys). Similarly, Western blot with the antiserum (1:500) was performed using the ovarian extract prepared with HBST buffer from three adult fish $(30 \mu \mathrm{g} /$ lane $)$.

To examine the effect of MO-mediated AroB knockdown, dot blot analysis using 120 larvae at $6 \mathrm{dpf}$ collected from 4 separate MO injection experiments were pooled and extracted similarly as described for the brain extract. Extracts containing $40 \mu \mathrm{g}$ protein $(3 \mu \mathrm{L})$ were spotted onto nitrocellulose membrane (GVS Life Science). The membrane was treated similarly as in Western blot except for the concentration of the secondary antibody at 1:2,000. Density of the blots were analyzed with NIH ImageJ software. Blots of embryo extracts treated with the pre-immunized rabbit serum were used as a negative control to subtract from the density obtained with the AroB antiserum. No changes were observed among controls (uninjected, standard control $\mathrm{MO}$, and inverted AroB MO) (data not shown). The effect of MO-mediated AroA knockdown was also examined by dot blot analysis. Briefly, pooled 120 embryos at $2 \mathrm{dpf}$ collected from 5 separate embryo cohorts were extracted. Extracts containing $30 \mu \mathrm{g}$ protein $(3 \mu \mathrm{L})$ were spotted onto nitrocellulose membrane and subjected to immunostaining using AroA antiserum at 1:500. No changes were observed among controls including inverted AroA MO (data not shown).

\section{5-HT Immunohistochemistry}

Whole-mount immunohistochemistry for 5-HT was carried out according to the previous studies $(48,49)$. 2-dpf embryos were fixed in $4 \%$ paraformaldehyde in PBS overnight at $4^{\circ} \mathrm{C}$. Fixed embryos were rinsed in PBS, bleached in $3 \% \mathrm{H}_{2} \mathrm{O}_{2}$ for $30 \mathrm{~min}$ and stored in methanol at $-20^{\circ} \mathrm{C}$ until use. For immunostaining, embryos were washed in PBS containing $0.1 \%$ Tween- 20 and $0.5 \%$ Triton X-100 (PBSTX), and then permeabilization was achieved by incubation in deionized $\mathrm{H}_{2} \mathrm{O}$ for $60 \mathrm{~min}$ at RT followed by $100 \%$ acetone for $8 \mathrm{~min}$ at $-20^{\circ} \mathrm{C}$. Non-specific binding was blocked by incubation in 10\% normal goat serum (NGS) and 3\% BSA for $3 \mathrm{~h}$ at RT. After several washes with PBSTX, embryos were incubated in rabbit polyclonal anti 5-HT (ImmunoStar) diluted at 1:500 in 10\% NGS/ PBS containing $0.3 \%$ Triton-X 100 for 2 days at $4^{\circ} \mathrm{C}$. After rinsing in PBSTX for $4 \mathrm{~h}$, embryos were incubated in the goat anti-rabbit IgG Alexa Fluor 488 (Molecular Probes Invitrogen Detection Technologies) diluted at 1:100 in 10\% NGS/PBS overnight at $4^{\circ} \mathrm{C}$. After thorough washing in PBSTX, embryos were mounted in $0.5 \%$ agarose and observed under the fluorescence microscope (Leica M165 FC). Negative controls processed by omitting incubation with the primary antibody or by replacing the primary antibody with normal rabbit serum showed no positive signals. For measurement of 5-HT-positive area, focus was adjusted on the field with the largest positive area, and NIH ImageJ software was used to quantify manually outlined areas. Immunostaining was performed using five to eight embryos per group, and the experiments were done in triplicate.

\section{RT-PCR}

Total RNA was extracted from larvae at 4 and $7 \mathrm{dpf}$ (25 larvae/ group) using ISOGEN II (Nippon Gene) and treated with DNase free (Ambion). cDNA was synthesized from $1 \mu \mathrm{g}$ total RNA using Reverse Transcription System (Promega). A total reaction volume of $25 \mu \mathrm{L}$ containing $2 \times$ GoTaq Green Master Mix (Promega), $10 \mu \mathrm{M}$ of each primer, and $1 \mu \mathrm{L}$ cDNA was subjected to PCR using Program Temp Control System PC708 (Astec). $\beta$-Actin was used as an internal control. Amplification conditions and primer sequences are listed in Table 2. The amplified products were separated on a $2 \%$ agarose gel. Levels of mRNAs expression were analyzed by NIH ImageJ software and normalized by the expression level in the control group at each developmental time. Experiments were done in triplicate.

\section{Heart Rate Measurement}

Embryos at $2 \mathrm{dpf}$ were individually placed in a well of a 12 -well culture plate containing $500 \mu \mathrm{L}$ of corresponding experimental medium and kept for 15 min to allow heartbeats to resume a steady rate. Heart beats were counted manually for $15 \mathrm{~s}$ under a stereo microscope (Leica 58APO). Ten embryos were used for each group. Experiments were repeated three times with eggs collected from different spawns.

\section{Thigmotaxis Assay}

Assay was performed according to the protocols described previously $(49,50)$. Briefly, zebrafish larvae at $6 \mathrm{dpf}$ were transferred into a 6-well tissue culture plate with one fish per well containing $4 \mathrm{~mL}$ EM. The bottom of each well was divided into two portions designated as inner and outer zones. After habituation at $28^{\circ} \mathrm{C}$ for $2 \mathrm{~h}$ followed by acclimation under the video camera for $5 \mathrm{~min}$, swimming activity was recorded for $5 \mathrm{~min}$. For each group, 12 larvae were used. Data from 36 larvae from three different spawns were pooled and analyzed to express \% of time a fish spent in the outer zone.

\section{Statistical Analysis}

Data are presented as mean \pm SEM. Statistical differences between groups were evaluated by one-way ANOVA followed by Tukey's or least significant difference post hoc test using IBM SPSS statistics version 19. Unpaired Student's $t$-test was used for the dot blot analysis. Kruskal-Wallis test and Mann-Whitney $U$ test were used for thigmotaxis assays, as the data did not meet the assumptions required for parametric testing. Significant differences were accepted when $p<0.05$.

\section{RESULTS}

\section{Effect of $E_{2}$ Exposure on Serotonergic Neuron}

5-HT-positive neurons were detected in the embryos at $2 \mathrm{dpf}$ by whole-mount fluorescent immunohistochemistry (Figure 1A). Positively stained neurons were located in pretectal and thalamic 
A

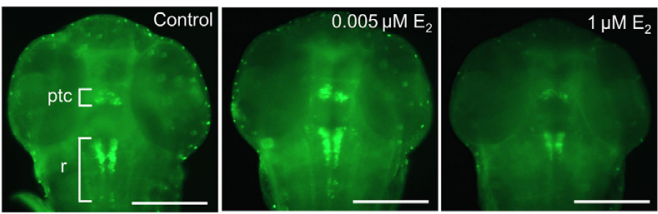

B

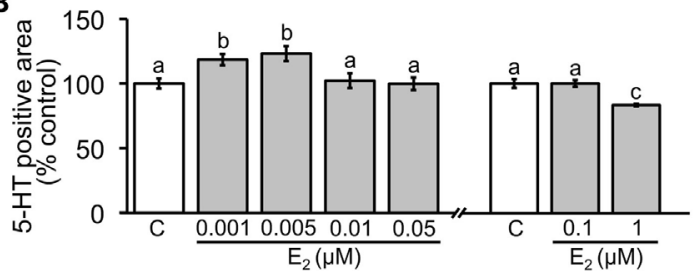

C

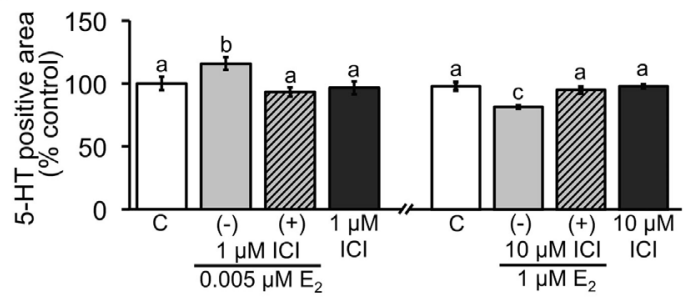

D
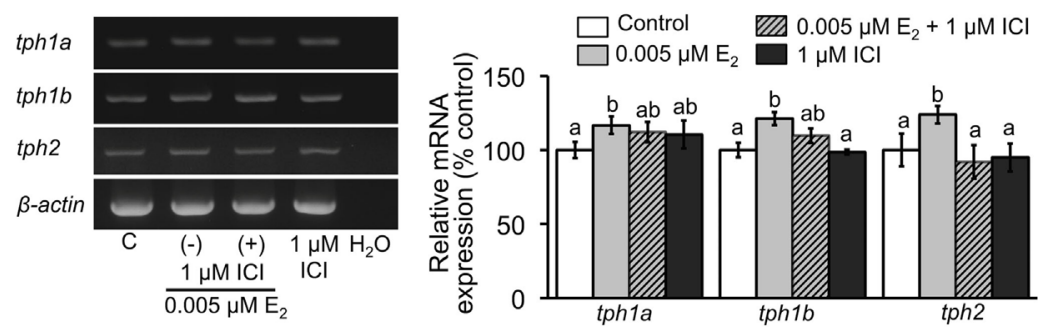

E
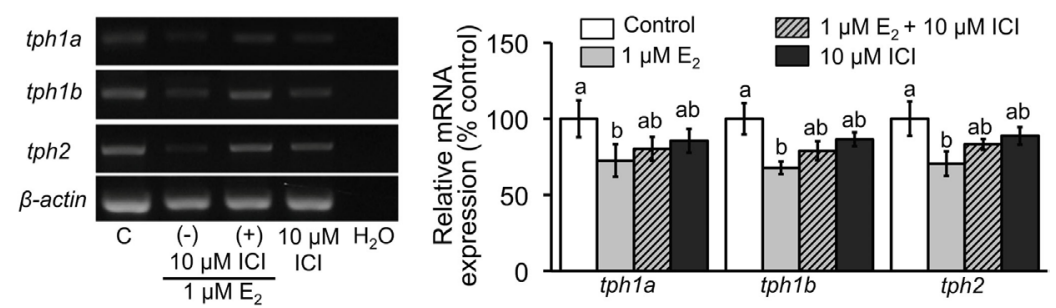

FIGURE 1 | Effect of $E_{2}$ on 5-HT-positive area and relative expression of tph isoforms. (A) Representative images of ventral view of head region showing 5-HT-positive cells in pretectal and thalamic complex (ptc) and raphe ( $r$ ) at $2 \mathrm{dpf}$. Scale bar: $200 \mu \mathrm{m}$. (B,C) Measurements of the area of 5-HT-positive neurons in the experiment of $E_{2}$ exposure and co-incubation of $E_{2}$ and ICl, respectively. (D,E) Semi-quantitative PCR for expression of tph isoforms in $4 \mathrm{dpf}$ larvae in the experiments of exposure to low and high doses of $\mathrm{E}_{2}$ and co-incubation with ICl, respectively. Data are presented as a mean $\pm \mathrm{SEM}$. Different letters in each graph indicate significant differences $(p<0.05)$.

complex and raphe as reported previously (48, 51-54). 5-HT-positive areas were significantly increased when exposed to low doses $\mathrm{E}_{2}(0.001$ and $0.005 \mu \mathrm{M})$ but decreased in high dose $(1 \mu \mathrm{M})$ exposure (Figure 1B). Effects of both low and high doses $\mathrm{E}_{2}$ were significantly reversed by addition of 1 or $10 \mu \mathrm{M}$ ICI, respectively (Figure 1C).

Relative expression levels of $t p h$ isoforms at $4 \mathrm{dpf}$ were analyzed by semi-quantitative PCR. Significant increase in expression was detected in all tph isoforms when embryos were exposed to low-dose $\mathrm{E}_{2}(0.005 \mu \mathrm{M})$. Addition of $1 \mu \mathrm{M}$ ICI completely reversed the decreased expression of $t p h 2$, while expressions of tph $1 a$ and $t p h 1 b$ were reversed partially (Figure 1D). Conversely, high-dose $\mathrm{E}_{2}$ exposure significantly decreased expression levels of all isoforms, which was partially reversed by addition of $10 \mu \mathrm{M}$ ICI (Figure 1E).

When the embryos were exposed to $\mathrm{E}_{2}$, the heart rate at $2 \mathrm{dpf}$ was significantly increased in the $0.005 \mu \mathrm{M}$ group, while significant decrease was found in the 0.1 and $1 \mu \mathrm{M}$ groups (Figure 2A). Addition of 1 and $10 \mu \mathrm{M}$ ICI significantly reversed the effects caused by low or high dose of $\mathrm{E}_{2}$, respectively (Figure 2A). To verify the role of serotonergic signaling in regulation of heart rate, effects of Q (5-HT agonist) and FLX (5-HT selective re-uptake 
A

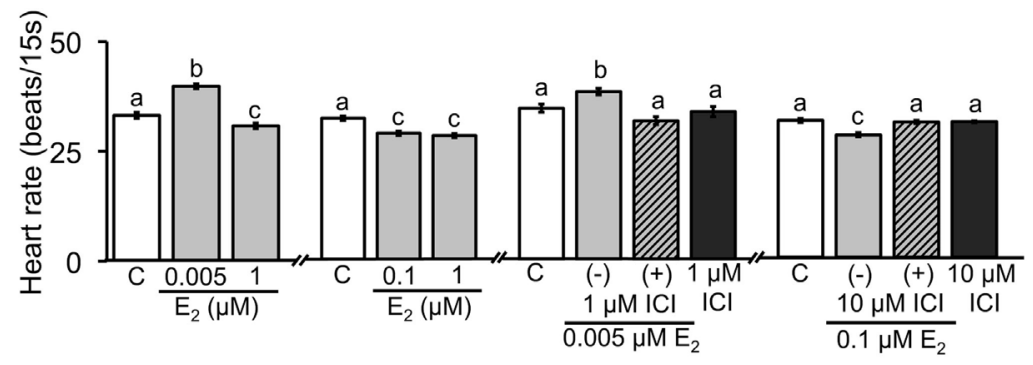

B

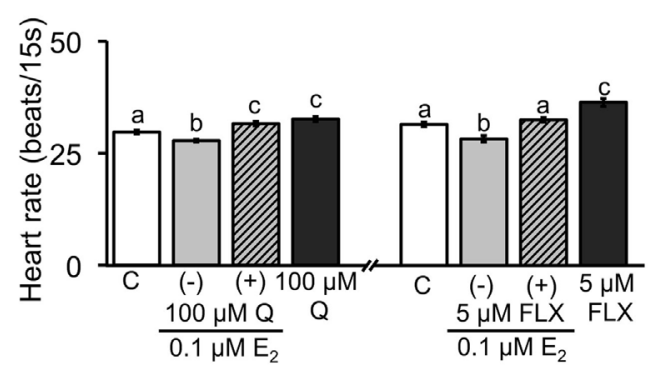

C

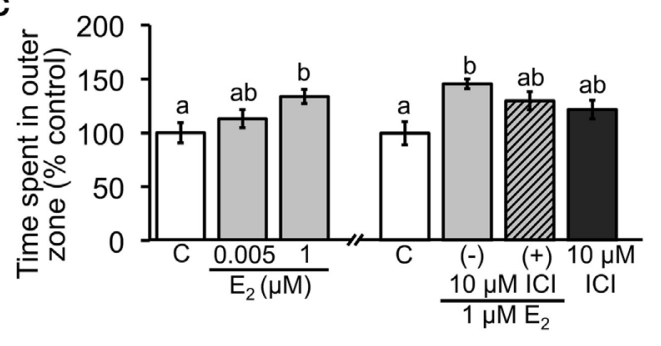

D

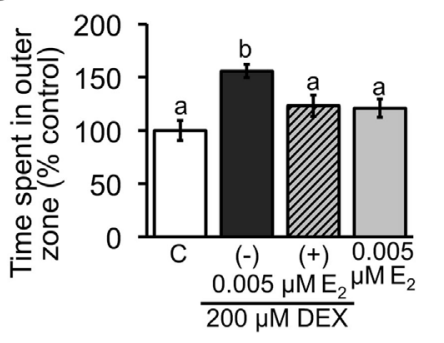

E
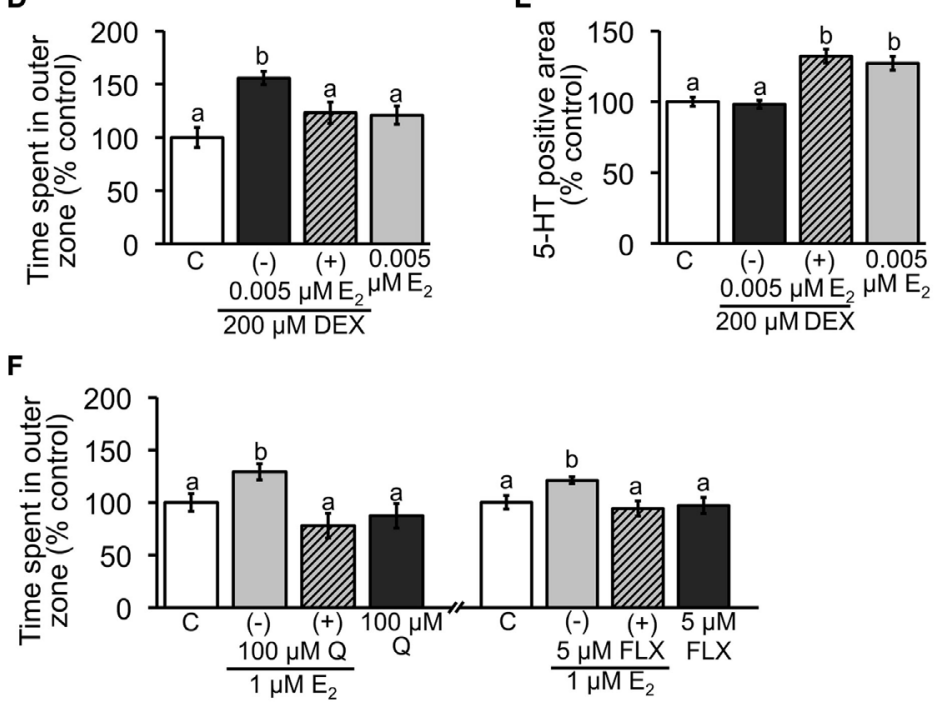

FIGURE 2 | Effect of $E_{2}$ on heart rate and thigmotaxis. Heart rate was measured in 2-dpf embryos; (A) exposure to low and high doses of $E_{2}$ and co-incubation with ICl; (B) co-incubation of $\mathrm{E}_{2}$ and $\mathrm{Q}$ or FLX to examine involvement of serotonin signaling. Thigmotaxis assay was performed to evaluate anxiety level in 6-dpf larvae; (C) exposure to low and high doses of $\mathrm{E}_{2}$ and co-incubation with ICl; (D) anxiolytic effect of low dose of $\mathrm{E}_{2}$ when larvae were exposed to $200 \mu \mathrm{M}$ DEX. (E) Measurements of 5-HT-positive neuron area in 2-dpf embryos exposed to DEX and low dose of $E_{2}$. (F) Effects of co-incubation of $E_{2}$ and $Q$ or FLX on thigmotaxis to examine involvement of serotonin signaling. Data are presented as a mean \pm SEM. Different letters in each graph indicate significant differences $(p<0.05)$.

inhibitor) were tested. Co-incubation with $0.1 \mu \mathrm{M} \mathrm{E}_{2}$ significantly reversed the decreased heart rate caused by $\mathrm{E}_{2}$. Heart rate was significantly increased when exposed to Q or FLX alone (Figure 2B).
Thigmotaxis assay was performed using 6-dpf larvae. Exposure to $1 \mu \mathrm{M} \mathrm{E} E_{2}$ increased the time fish spent in outer zone, suggesting that anxiety was increased, but no significant difference was 
observed in $0.005 \mu \mathrm{ME}_{2}$ group (Figure 2C). Addition of $10 \mu \mathrm{M} \mathrm{ICI}$ partially reversed the increase caused by $1 \mu \mathrm{M} \mathrm{E}_{2}$ (Figure 2C). To further examine the effect of low-dose $\mathrm{E}_{2}$, embryos were exposed to $200 \mu \mathrm{M} \mathrm{DEX}$ and subjected to the assay. DEX alone increased the time, but co-incubation with $0.005 \mu \mathrm{M} \mathrm{E}_{2}$ significantly reduced the increase (Figure 2D). Immunostaining for 5-HT showed that co-incubation of low-dose $\mathrm{E}_{2}$ and DEX increased the positive staining, although DEX alone had no effect (Figure 2E). To verify the role of serotonergic signaling in thigmotaxis assay, effects of Q and FLX were tested. Both Q and FLX significantly decreased the time fish spent in outer zone caused by $1 \mu \mathrm{M} \mathrm{E}_{2}$ exposure (Figure 2F).

\section{Validation of MO-Mediated Knockdown Using the Specific Antisera}

Specificity of the antisera to AroB and AroA was examined by Western blot. The anti-AroB revealed a single band at the expected size of $50 \mathrm{kDa}$ in brain extract from the fish exposed to $\mathrm{E}_{2}$ at $25 \mathrm{ng} / \mathrm{L}$ (47) (Figure 3A). The anti-AroA detected a single band at the expected size of $75 \mathrm{kDa}$ in the ovarian extract (Figure 3A), which is in agreement with the previous study (55). In addition, immunohistochemistry of the ovary showed similar localization of AroA as previously described (56) (data not shown).
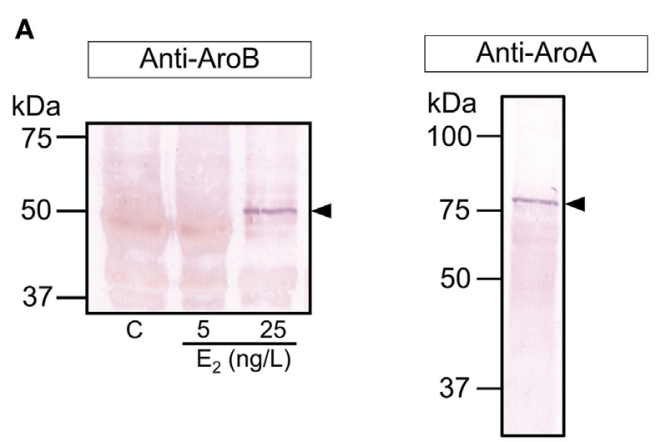

B
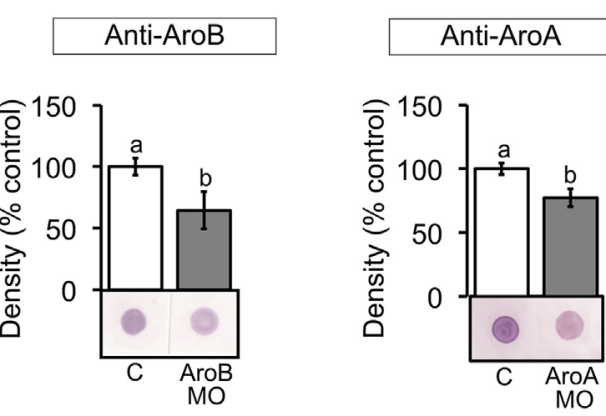

FIGURE 3 | Validation of MO-mediated knockdown on translation. (A) Western blots of brain extracts from control and $E_{2}$ exposed fish and ovarian extract from untreated fish were stained with the antiserum to AroB and AroA, respectively, showing a positive band at the expected size for each aromatase as indicated by arrowheads. (B) Dot blots of 6 and $2 \mathrm{dpf}$ larval extracts using the antiserum to $\mathrm{AroB}$ and AroA, respectively, were analyzed. Representative blots are shown in each graph. Data are presented as a mean \pm SEM. Different letters in each graph indicate significant differences $(p<0.05)$.
The dot blot analysis of the larval extracts showed that both AroB and AroA MO injections significantly decreased immunoreactivity compared to the uninjected control, indicating decreased translation of AroB and AroA, respectively (Figure 3B). Std MO, InvB, or InvA MO did not show any significant difference compared to the uninjected control (data not shown).

\section{Effect of MO-Mediated Knockdown of AroB on Serotonergic Neuron}

When AroB MO was injected, 5-HT-positive area was significantly decreased in the $5 \mathrm{ng} / \mathrm{L}$ group and partially decreased in the $2.5 \mathrm{ng} / \mathrm{nL}$ group compared to the uninjected control (Figure 4A). Injections of Std $\mathrm{MO}$ and InvB MO did not show any significant difference in 5-HT-positive areas compared to the uninjected control (Figure 4A). Moreover, the injection of AroA did not show any changes (Figure 4A). The decrease in 5-HT-positive area caused by AroB was completely rescued by co-injection of $30 \mathrm{pg} / \mathrm{nL}$ AroB mRNA (Figure 4B) and partially rescued by $\mathrm{E}_{2}$ exposure at $0.1 \mu \mathrm{M}$ (Figure 4C). When p53 MO was co-injected with AroB MO to examine off-target effect, no significant difference in 5-HT-positive area was observed, suggesting that decrease in 5-HT-positive area caused by AroB MO is not due to apoptosis caused by $p 53$ activation (Figure $4 \mathrm{D}$ ).

The effect of AroB MO injection on relative expression of tph isoforms was evaluated by semi-quantitative PCR using 7-dpf larvae. While expression levels of tphla and tph $1 b$ showed no significant changes, expression of tph2 isoform was significantly decreased and partially rescued by $\mathrm{E}_{2}$ exposure at $0.1 \mu \mathrm{M}$ (Figure 4E).

Heart rate of AroB MO injected embryos was significantly decreased compared to the uninjected or Std MO and InvB MO injected controls (Figure 5A). The decrease caused by AroB MO was rescued either by co-injection of AroB mRNA or by exposure to $0.1 \mu \mathrm{M} \mathrm{E}_{2}$ (Figures 5B,C). Exposure to $100 \mu \mathrm{M} \mathrm{Q}$ as well as to $5 \mu \mathrm{M}$ FLX (Figure 5D) reversed the decrease to the control level.

In thigmotaxis assay, AroB MO injection caused significant increase in time fish spent in outer zone compared to the uninjected, Std MO injected, and InvB MO injected controls (Figure 5E). This effect of AroB MO was rescued either by co-injection of AroB mRNA or by exposure to $0.1 \mu \mathrm{M} \mathrm{E}_{2}$ (Figures 5F,G). Exposure to $100 \mu \mathrm{M}$ Q as well as to $5 \mu \mathrm{M}$ FLX reversed the time fish spent in outer zone increased by AroB MO injection (Figure $\mathbf{5 H}$ ).

\section{DISCUSSION}

The aim of this study is to elucidate the role of estradiol and brain aromatase in modulation of serotonergic neurons in early development of zebrafish, as the early ontogeny of serotonergic system may be one of the important factors for neuronal growth and brain development. We demonstrated that exogenous administration of $E_{2}$ biphasically affected parameters such as 5-HT-positive areas, relative expression of $t p h$ isoforms, heart rate and thigmotactic behavior with stimulation and suppression of serotonin system at the low dose and the high dose, 

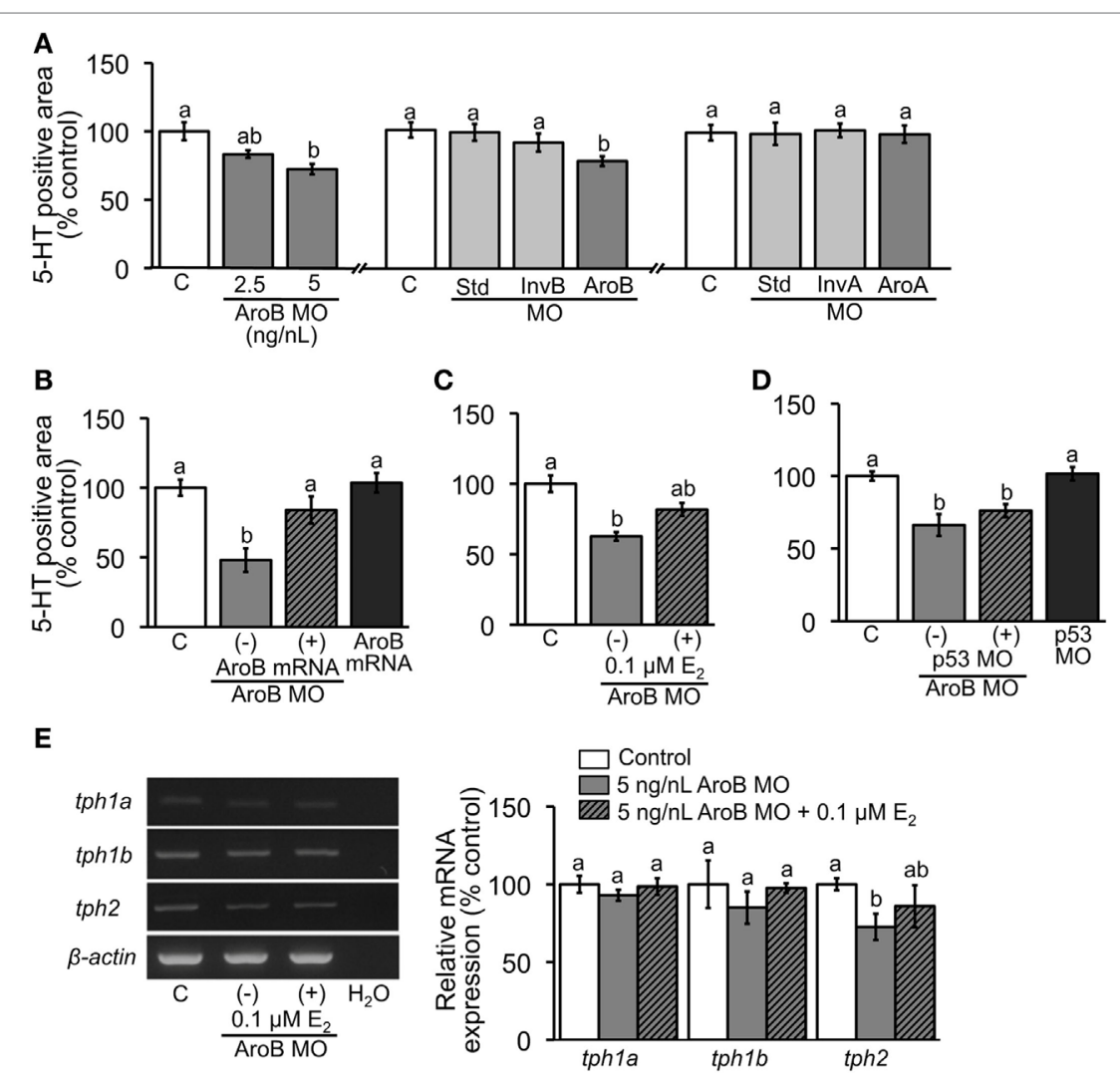

FIGURE 4 | AroB MO-mediated effect on serotonergic neuron. 5-HT-positive neuron area was measured in 2-dpf embryos; (A) injection of AroB MO and control MOs (Std MO, InvB MO and AroA MO); (B,C) co-injection of AroB mRNA and exposure to $\mathrm{E}_{2}$, respectively, to rescue the effect of AroB MO; (D) co-injection of p53 $\mathrm{MO}$ to test off-target effect of AroB MO. (E) Semi-quantitative PCR measurement of expression of tph isoforms in 6-dpf larvae injected with AroB MO with and without exposure to $E_{2}$. Data are presented as a mean \pm SEM. Different letters in each graph indicate significant differences $(p<0.05)$.

respectively, through acting on ER. On the other hand, activities of serotonergic neurons were suppressed by AroB MO-mediated knockdown, suggesting that brain-formed $\mathrm{E}_{2}$ in early development stimulates serotonergic neurons, which is in accordance with the results of the low-dose $E_{2}$. Recent study shows that $\mathrm{MO}$-mediated brain aromatase knockdown results in a significant decrease in $\mathrm{E}_{2}$ concentration in $48 \mathrm{hpf}$ embryos (57), which supports that our MO experiments reflect the reduction of estrogen production.

Non-monotonic dose responses of hormones and endocrine-disrupting chemicals have been widely documented (58). Estrogen among other hormones is known to exhibit biphasic dose-dependent effects in various physiological processes (59-66). However, only limited information is available in regards to serotonin system. There is one study in fish showing that low dose of $\mathrm{E}_{2}$ stimulated monoamine oxidase activity and decreased 5-HT content in hypothalamus in ovariectomized catfish, while the result was opposite for high dose (67). Our study demonstrates that biphasic dose-dependent effects of $E_{2}$ on serotonergic neuron in fish, and shows that the effects or both low and high doses are mediated through ER, indicating physiological relevance. The effect of the low dose of $E_{2}$, stimulating serotonergic neuron, is likely to reflect the role of endogenous $\mathrm{E}_{2}$ in embryos, as AroB MO-mediated effects demonstrate that brain-formed estrogen is necessary to maintain activity of serotonergic neuron in embryos. Mechanisms of biphasic responses are complex, but may be in part controlled by downregulation and desensitization of receptors $(57,68)$. Thus, effects of high doses of $\mathrm{E}_{2}$ on serotonergic neuron in this study may be due to downregulation/desensitization of ERs. Sequence analysis of the promoter region of zebrafish $t p h$ isoforms shows the presence of $1 / 2$ ERE in the upstream of transcription start site in all isoforms, suggesting possible nuclear action of estrogen, though their functional analysis is yet to be reported. In human serotonergic cell line, binding of $\mathrm{E}_{2}$ and $\mathrm{ER} \beta$ has been shown to directly interact with 1/2 ERE of tph2 promoter to elicit gene expression (39). In addition to the classical action of $\mathrm{E}_{2}$ on nuclear receptors membrane ERs plays an important role in brain $(69,70)$. Interaction between membrane ERs and the metabolic glutamate receptor in the brain provides a rapid and transient $\mathrm{E}_{2}$ action $(71,72)$. Membrane bound G-protein-coupled ER, GPER/GPR30, also known to be involved in modulating rapid non-genomic action of $E_{2}$, plays a role in several brain areas (73). Estrogen action through GPR30 has been suggested in regulation of serotonergic neuron in mammals (74). Further studies are required to elucidate the mechanisms by which estrogen regulates serotonergic neuron in zebrafish. 

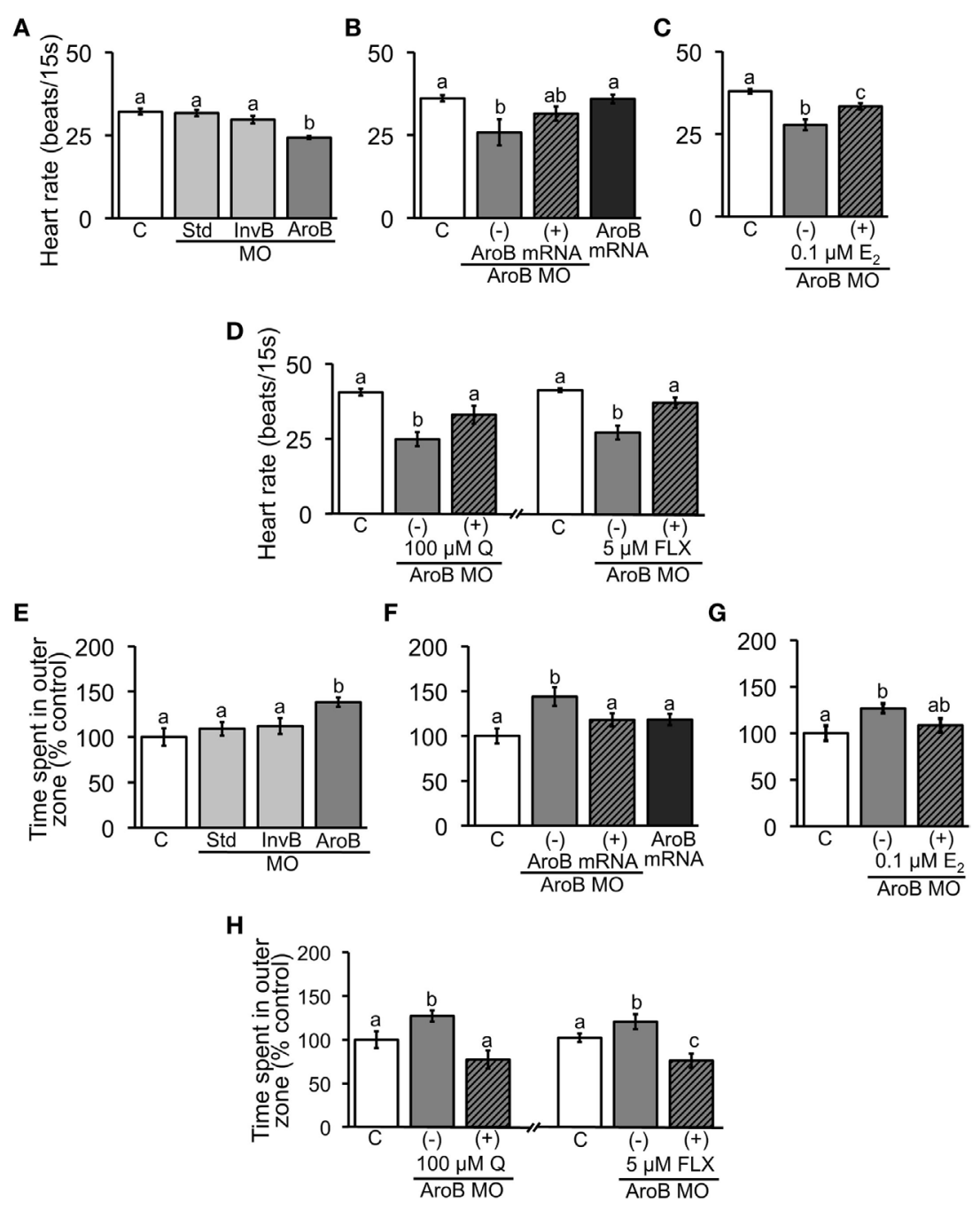

FIGURE 5 | AroB MO-mediated effect on heart rate and thigmotaxis. Heart rate was measured in 2-dpf embryos; (A) injection of AroB MO and control MOs; $(\mathbf{B}, \mathbf{C})$ co-injection of AroB mRNA and exposure to $\mathrm{E}_{2}$, respectively, to rescue the effect of AroB MO; (D) injection of AroB MO with and without exposure to $Q$ and FLX to examine involvement of serotonin signaling. Thigmotaxis assay was conducted using 6-dpf larvae; (E) injection of AroB MO and control MOs; $(\mathbf{F}, \mathbf{G}) \mathrm{co}$-injection of AroB mRNA and exposure to $\mathrm{E}_{2}$, respectively, to rescue the effect of AroB MO; $\mathbf{( H )}$ injection of AroB $\mathrm{MO}$ with and without exposure to $Q$ and FLX to examine involvement of serotonin signaling. Data are presented as a mean $\pm \mathrm{SEM}$. Different letters in each graph indicate significant differences $(p<0.05)$.

Attenuation of serotonergic neuron by AroB MO-mediated knockdown clearly demonstrated that brain-formed estrogen is necessary to maintain the serotonin system to control heart rate and anxiety behavior in early development of zebrafish. Validity of AroB knockdown was supported by several lines of evidence. Immunoreactivity to the antiserum specific to AroB was decreased in AroB MO injected embryos. In addition to no significant effects found in the controls including standard $\mathrm{MO}$, inverted AroB MO and AroA MO-injected embryos, AroB MO-mediated effects were rescued by co-injection of AroB mRNA and exposure to $E_{2}$. Off-target effect of $\mathrm{MO}$ injection was also examined by knockdown of $p 53$, showing that the decreased 5-HT-positive area caused by AroB MO is not through activation of $p 53$. The decrease in 5-HT-positive area by AroB MO injection indicates that brain-formed estrogen stimulates $5-\mathrm{HT}$ synthesis, which is in accordance with the stimulatory effect of low-dose $\mathrm{E}_{2}$. When the relative expressions of tph isoforms were examined in AroB MO injected embryos, only tph2 expression was significantly decreased by AroB MO, which is well supported by the previous studies showing tph 2 but not tph 1 is expressed in raphe 5-HT neurons $(54,75,76)$. Expression of tph2 in 5-HT neurons in pretectal and hypothalamic complex starts to appear at $60 \mathrm{hpf}$ (76). On the other hand, whereas in the exposure experiments, expressions of all isoforms were affected by $\mathrm{E}_{2}$; increased by low dose and decreased by high dose. The results support the previous studies reporting that $t p h 2$ expressed in brain is responsible for 5-HT synthesis in the zebrafish $(27,28$, 54). Thus, we provide the evidence that brain-formed estrogen stimulates tph2 expression to maintain 5-HT content in the serotonin neuron. The effects of $E_{2}$ exposure on tph isoforms 
indicate $\mathrm{E}_{2}$ also modulates serotonin biosynthesis in tissues outside the brain. 5-HT has been reported to be produced in various organs including intestine which is the major source of 5 - HT in the body and TPH1 is responsible for its synthesis $(54,77)$. Investigation of estrogen regulation of serotonin production in intestine during development would be a future research interest.

The parameters of physiological functions of serotonin system, heart rate, and thigmotactic behavior were measure to verify the activity of serotonergic neuron. The results were in accordance to the changes in 5-HT levels in the neurons; the increased 5-HT levels are accompanied by the increased heart rate and decreased thigmotactic behavior, while the contrary was true for the decreased 5-HT levels. Serotonin is known to be involved in cardiovascular function, and the effect of central serotonergic neuron is mediated through autonomic nervous system in mammals (18). Our result of the low-dose $(0.005 \mu \mathrm{M}) \mathrm{E}_{2}$ which increased heart rate corroborates the effect of MO-mediated AroB knockdown, indicating that nanomolar level of brain-formed estrogen, or even lower level in the tissue, stimulates serotonergic neuron to increase the heart rate. Exposure to quipazine (serotonin agonist), or fluoxetine (selective serotonin reuptake inhibitor, SSRI) completely reversed the decreased heart rate caused by the high dose $(0.1 \mu \mathrm{M}) \mathrm{E}_{2}$, or AroB MO injection confirming that heart rate is under the control of serotonin signaling. Taken together with a recent study showing that GPER in the pituitary of zebrafish embryo regulates heart rate through thyroid hormone (78), estrogen in brain centrally regulates heart rate through various mechanisms. On the other hand, cardiac functions are directly regulated by estrogen (79) and aromatase has been detected in the heart tissues such as myocardium in mice (80-82). Therefore, it is possible that AroB MO injection may affect aromatase expression in the heart and locally produced estrogen modulates heart rate. In some teleost fish, both ovarian and brain aromatases are expressed in the heart (83-85), but in ricefield eel only brain aromatase is detected (86), while only ovarian aromatase is present in spotted scat (87). These difference may be due to technical difference as well as differences in species and developmental and physiological status. Our preliminary analysis indicated the expression of ovarian aromatase but not the brain form in adult zebrafish heart (data not shown), suggesting that our result of MO injection is likely to be mediated through knockdown of brain aromatase expressed in the brain not in the heart. However, expression of aromatase in the heart during development needs to be verified.

Thigmotaxis is an evolutionally conserved behavior associated with fear and has been shown to be affected by anxiolytic and anxiogenic compounds (88); thus, it has been used to measure anxiety levels in animals including fish (89-92). Our present study shows the high dose $\mathrm{E}_{2}(1 \mu \mathrm{M})$, which decreased the 5 -HT level, significantly increased anxiety (increased time spent in outer zone), and this increase was abolished by addition of 5-HT agonist (Q) or SSRI (FLX), indicating the effect of high dose $\mathrm{E}_{2}$ is mediated through serotonin signaling. Similarly, increased anxiety by AroB MO was also abolished by Q or FLX, which supports our hypothesis that brain-formed estrogen modulates serotonergic neuron. Despite our expectation, the low-dose $\mathrm{E}_{2}(0.005 \mu \mathrm{M})$, which increased the 5-HT level, did not cause reduction of anxiety. Therefore, we further examined to see if the low-dose $\mathrm{E}_{2}$ exerts anxiolytic effect in the larvae exposed to DEX to induce stress, and indeed, low-dose $\mathrm{E}_{2}$ decreased the anxiety level. Thus, our data demonstrate a negative correlation between anxiety behavior and 5-HT level, which is in accordance with previous studies. In mammals, depletion of 5-HT level in rat brain induces anxiety (93) and acute reduction of tryptophan increases the anxiety level in patients of a social anxiety disorder (94). The role of 5-HT in anxiety is also reported in zebrafish (20, 95). Buspirone, partial agonist for 5-HT1A receptor, exerts anxiolytic-like effect in zebrafish (96). The phenotype of zebrafish leopard strain, which is characterized by increased anxiety-like behavior, is rescued by acute treatment with FLX (97). Taken together, we provide the evidence that brain-formed $\mathrm{E}_{2}$ has an important role in modulating anxiety through serotonergic transmission.

In contrast to mammalian brain, where aromatase is expressed in both neuron and glia $(98,99)$, it is well documented that brain aromatase in fish is exclusively expressed in RGCs along the ventricles of forebrain, midbrain, and hindbrain serving as neural progenitors $(10,11,47)$. While most RGCs are transformed into astrocytes by the time of adulthood in mammalian brain (100), presence of RGCs persists throughout the lifespan of zebrafish, which is considered to be one of the contributing factors for high capacity of neuronal proliferation (101). On the other hand, serotonin is known to play a role in neurogenesis (102). In adult zebrafish, it has been reported that projection of 5-HT neurons in raphe to ventricular surface of the brain, where highly proliferative cells are found. In addition, expression of 5-HT receptors are localized in ventricular surface in larval and adult zebrafish $(27,103)$. Thus, it may be possible that RGCs in ventricular surface are innervated by 5 -HT neurons in raphe and modulated for neurogenesis. Interestingly, it has been reported that AroB-positive RGCs in PVO area in adult zebrafish has an ability to differentiate into serotonergic neuron (104). Taken together with our present study providing the evidence that brain-formed estrogen is necessary to maintain the levels of 5 -HT in neurons in raphe, we can hypothesize that differentiation of AroB-expressing RGCs in serotonin neurons is regulated by serotonin neuron in raphe, whose activity is modulated by estrogen produced by AroB. It has been shown that placenta aromatase activity and expression are stimulated by serotonergic 5-HT2A receptor signaling (105). In goldfish, AroB expression in RGCs in vitro is upregulated by dopamine with modulation by $\mathrm{E}_{2}$ (106). Nonetheless, estrogen biosynthesis and homeostasis in CNS are regulated and fine-tuned by multiple factors like neurotransmitters and hormones, so that diverse functions of estrogen can be coordinated.

In conclusion, this study demonstrates that estradiol exhibits a biphasic effect on serotonergic neuron, and that brain aromatase, thus brain-formed estrogen plays a significant role in modulating serotonin levels to sustain appropriate development and functions of serotonergic neurons which regulate heart rate and anxiety behavior in zebrafish embryos and larvae. Considering the role of serotonergic neurons in neural 
development and neurogenesis, it is possible to postulate that one of the mechanisms of brain aromatase and brain-formed estrogen to regulate neurogenesis in teleost brain may be through modulation of serotonergic system, which awaits future investigation.

\section{ETHICS STATEMENT}

All experimental procedures and maintenance of fish were conducted in accordance with the Guide for Care and Use of Laboratory Animals published by the US National Institutes of Health.

\section{REFERENCES}

1. Simpson ER, Davis SR. Minireview: aromatase and the regulation of estrogen biosynthesis-some new perspectives. Endocrinology (2001) 142(11): 4589-94. doi:10.1210/endo.142.11.8547

2. Cui J, Shen Y, Li R. Estrogen synthesis and signaling pathways during ageing: from periphery to brain. Trends Mol Med (2013) 19(3):197-209. doi:10.1016/j.molmed.2012.12.007

3. Kishida M, Callard GV. Distinct cytochrome P450 aromatase isoforms in zebrafish (Danio rerio) brain and ovary are differentially programmed and estrogen regulated during early development. Endocrinology (2001) 142(2):740-50. doi:10.1210/endo.142.2.7928

4. Callard GV, Greytak SR, Novillo A, Cotter CA, Mayer RK. Brain aromatase in fish: perspective and comparative approaches. In: Balthazart J, Ball G, editors. Brain Aromatase, Estrogen, and Behavior. New York: Oxford University Press (2013). p. 13-42.

5. Pasmanik M, Callard GV. Changes in brain aromatase and 5 alpha-reductase activities correlate significantly with seasonal reproductive cycles in goldfish (Carassius auratus). Endocrinology (1988) 122(4):1349-56. doi:10.1210/endo122-4-1349

6. Zupanc GKH. Adult neurogenesis and neuronal regeneration in the brain of teleost fish. JPhysiol Paris (2008) 102(4-6):357-73. doi:10.1016/j. jphysparis.2008.10.007

7. Adolf B, Chapouton P, Lam CS, Topp S, Tannhäuser B, Strähle U, et al. Conserved and acquired features of adult neurogenesis in the zebrafish telencephalon. Dev Biol (2006) 295(1):278-93. doi:10.1016/j.ydbio.2006. 03.023

8. Grandel H, Kaslin J, Ganz J, Wenzel I, Brand M. Neural stem cells and neurogenesis in the adult zebrafish brain: origin, proliferation dynamics, migration and cell fate. Dev Biol (2006) 295(1):263-77. doi:10.1016/j.ydbio.2006. 03.040

9. Schmidt R, Strähle U, Scholpp S. Neurogenesis in zebrafish - from embryo to adult. Neural Dev (2013) 8:3. doi:10.1186/1749-8104-8-3

10. Forlano PM, Deitcher DL, Myers DA, Bass AH. Anatomical distribution and cellular basis for high levels of aromatase activity in the brain of teleost fish: aromatase enzyme and mRNA expression identify glia as source. J Neurosci (2001) 21(22):8943-55. doi:10.1523/JNEUROSCI.21-22-08943.2001

11. Tong SK, Mouriec K, Kuo MW, Pellegrini E, Gueguen MM, Brion F, et al. A cyp19alb-gfp (aromatase B) transgenic zebrafish line that expresses GFP in radial glial cells. Genesis (2009) 47:67-73. doi:10.1002/dvg.20459

12. Radakovits R, Barros CS, Belvindrah R, Patton B, Müller U. Regulation of radial glial survival by signals from the meninges. JNeurosci (2009) 29(24):7694-705. doi:10.1523/JNEUROSCI.5537-08.2009

13. Sawyer SJ, Gerstner KA, Callard GV. Real-time PCR analysis of cytochrome P450 aromatase expression in zebrafish: gene specific tissue distribution, sex differences, developmental programming, and estrogen regulation. Gen Comp Endocrinol (2006) 147(2):108-17. doi:10.1016/j.ygcen.2005.12.010

14. Diotel N, Vaillant C, Gabbero C, Mironov S, Fostier A, Gueguen MM, et al. Effects of estradiol in adult neurogenesis and brain repair in zebrafish. Horm Behav (2013) 63(2):193-207. doi:10.1016/j.yhbeh.2012.04.003

15. Graeff FG, Guimarães FS, De Andrade TGCS, Deakin JFW. Role of 5-HT in stress, anxiety and depression. Pharmacol Biochem Behav (1996) 54(1): 129-41. doi:10.1016/0091-3057(95)02135-3

\section{AUTHOR CONTRIBUTIONS}

$\mathrm{ZU}$ and MK designed the experiments. ZU performed the experiments and analyzed the data. ZU and MK wrote the paper.

\section{ACKNOWLEDGMENTS}

ZU was supported by MEXT (Ministry of Education, Culture, Sports, Science and Technology, Japan) scholarship. We would like to thank Prof. Akiyoshi Takahashi and Assoc. Prof. Kanta Mizusawa for helping ZU to generate AroB mRNA, and Prof. Kazufumi Takamune for his support with western blot experiments.

16. Michelsen KA, Schmitz C, Steinbusch HWM. The dorsal raphe nucleus-from silver stainings to a role in depression. Brain Res Rev (2007) 55(2):329-42. doi:10.1016/j.brainresrev.2007.01.002

17. Bravo JA, Dinan TG, Cryan JF. Early-life stress induces persistent alterations in 5-HT1A receptor and serotonin transporter mRNA expression in the adult rat brain. Front Mol Neurosci (2014) 7(24):1-9. doi:10.3389/fnmol 2014.00024

18. Côté F, Fligny C, Fromes Y, Mallet J, Vodjdani G. Recent advances in understanding serotonin regulation of cardiovascular function. Trends $\mathrm{Mol} \mathrm{Med}$ (2004) 10(5):232-8. doi:10.1016/j.molmed.2004.03.007

19. Nakamura K. The role of the dorsal raphé nucleus in reward-seeking behavior. Front Integr Neurosci (2013) 7(60):1-18. doi:10.3389/fnint.2013 00060

20. Herculano AM, Maximino C. Serotonergic modulation of zebrafish behavior: towards a paradox. Prog Neuropsychopharmacol Biol Psychiatry (2014) 55:50-66. doi:10.1016/j.pnpbp.2014.03.008

21. Berg DA, Belnoue L, Song H, Simon A. Neurotransmitter mediated control of neurogenesis in the adult vertebrate brain. Development (2013) 140(2):2548-61. doi:10.1242/dev.088005

22. Charnay Y, Léger L. Brain serotonergic circuitries. Dialogues Clin Neurosci (2010) 12(4):471-87

23. Lesch KP, Waider J. Serotonin in the modulation of neural plasticity and networks: implications for neurodevelopmental disorders. Neuron (2012) 76(1):175-91. doi:10.1016/j.neuron.2012.09.013

24. Herlenius E, Lagercrantz H. Neurotransmitters and neuromodulators during early human development. Early Hum Dev (2001) 65(1):21-37. doi:10.1016/ S0378-3782(01)00189-X

25. Sodhi MS, Sanders-Bush E. Serotonin and brain development. Int Rev Neurobiol (2004) 59:111-74. doi:10.1016/S0074-7742(04)59006-2

26. Sundström E, Kolare S, Souverbie F, Samuelsson EB, Pschera H, Lunell NO et al. Neurochemical differentiation of human bulbospinal monoaminergic neurons during the first trimester. Brain Res Dev Brain Res (1993) 75(1):1-12. doi:10.1016/0165-3806(93)90059-J

27. Lillesaar C. The serotonergic system in fish. JChem Neuroanat (2011) 41(4):294-308. doi:10.1016/j.jchemneu.2011.05.009

28. Gaspar P, Lillesaar C. Probing the diversity of serotonin neurons. Philos Trans R Soc Lond B Biol Sci (2012) 367(1601):2382-94. doi:10.1098/rstb. 2011.0378

29. Barreiro-Iglesias A, Mysiak KS, Scott AL, Reimer MM, Yang Y, Becker CG, et al. Serotonin promotes development and regeneration of spinal motor neurons in zebrafish. Cell Rep (2015) 13(5):924-32. doi:10.1016/j.celrep.2015 09.050

30. McEwen BS, Elves SE. Estrogen actions in the central nervous system. Endocr Rev (1999) 20(3):279-307. doi:10.1210/edrv.20.3.0365

31. Bethea CL, Lu NZ, Gundlah C, Streicher JM. Diverse actions of ovarian steroids in the serotonin neural system. Front Neuroendocrinol (2002) 23(1):41-100. doi:10.1006/frne.2001.0225

32. Pecins-Thompson M, Brown NA, Kohama SG, Bethea CL. Ovarian steroid regulation of tryptophan hydroxylase mRNA expression in rhesus macaque. J Neurosci (1996) 16(21):7021-9. doi:10.1523/JNEUROSCI.16-2107021.1996

33. Pecins-Thompson M, Brown NA, Bethea CL. Regulation of serotonin reuptake transporter mRNA expression by ovarian steroids in rhesus macaques. 
Brain Res Mol Brain Res (1998) 53(1-2):120-9. doi:10.1016/S0169-328X(97) 00286-6

34. Pecins-Thompson M, Bethea CL. Ovarian steroid regulation of serotonin-1A autoreceptor messenger RNA expression in the dorsal raphe of rhesus macaques. Neuroscience (1999) 89(1):267-77. doi:10.1016/S0306-4522(98) 00326-1

35. Gundlah C, Lu NZ, Mirkes SJ, Bethea CL. Estrogen receptor beta (ER $\beta$ ) mRNA and protein in serotonin neurons of macaques. Mol Brain Res (2001) 91:14-22. doi:10.1016/S0169-328X(01)00108-5

36. Sheng Z, Kawano J, Yanai A, Fujinaga R, Tanaka M, Watanabe Y, et al. Expression of estrogen receptors $(\alpha, \beta)$ and androgen receptor in serotonin neurons of the rat and mouse dorsal raphe nuclei; sex and species differences. Neurosci Res (2004) 49:185-96. doi:10.1016/j.neures.2004.02.011

37. Bethea CL, Phu K, Belikova Y, Bethea SC. Localization and regulation of reproductive steroid receptors in the raphe serotonin system of male macaques. J Chem Neuroanat (2015) 6(6-67):19-27. doi:10.1016/j.jchemneu. 2015.04.001

38. Donner N, Handa RJ. Estrogen receptor beta regulates the expression of tryptophanhydroxylase 2 mRNA within serotonergic neurons of the rat dorsal raphe nuclei. Neuroscience (2009) 163(2):705-18. doi:10.1016/j. neuroscience.2009.06.046

39. Hiroi R, Handa RJ. Estrogen receptor- $\beta$ regulates human tryptophan hydroxylase- 2 through an estrogen response element in the 5 ' untranslated region. J Neurochem (2013) 127(4):487-95. doi:10.1111/jnc.12401

40. Tsai CL, Wang LH, Chang CF, Kao CC. Effects of gonadal steroids on brain serotonergic and aromatase activity during the critical period of sexual differentiation in tilapia, Oreochromis mossambicus. J Neuroendocrinol (2000) 12(9):894-8. doi:10.1046/j.1365-2826.2000.00536.x

41. Thilagam H, Gopalakrishnan S, Bo J, Wang KJ. Comparative study of $17 \beta-$ estradiol on endocrine disruption and biotransformation in fingerlings and juveniles of Japanese sea bass Lateolabrax japonicas. Mar Pollut Bull (2014) 85:332-7. doi:10.1016/j.marpolbul.2014.05.024

42. Diotel N, Do Rego JL, Anglade I, Vaillant C, Pellegrini E, Vaudry H, et al. The brain of teleost fish, a source, and a target of sexual steroids. Front Neurosci (2011) 5:137. doi:10.3389/fnins.2011.00137

43. Coumailleau P, Pellegrini E, Adrio F, Diotel N, Nicolau JC, Nasri A, et al. Aromatase, estrogen receptors and brain development in fish and amphibians. Biochim Biophys Acta (2015) 1849(2):152-62. doi:10.1016/j. bbagrm.2014.07.002

44. Langheinrich U, Hennen E, Stott G, Vacun G. Zebrafish as a model organism for the identification and characterization of drugs and genes affecting p 53 signaling. Curr Biol (2002) 12(23):2023-8. doi:10.1016/S0960-9822(02)01319-2

45. Robu ME, Larson JD, Nasevicius A, Beiraghi S, Brenner C, Farber SA, et al. p53 activation by knockdown technologies. PLoS Genet (2007) 3(5):e78. doi:10.1371/journal.pgen.0030078

46. Bashammakh S. The Developmental Role of the Serotonin System [Dissertation Thesis]. Berlin: Freie Universität Berlin (2007). Available from: http://edocs. fu-berlin.de/diss/receive/FUDISS_thesis_000000003162

47. Menuet A, Pellegrini E, Brion F, Gueguen MM, Anglade I, Pakdel F, et al. Expression and estrogen-dependent regulation of the zebrafish brain aromatase gene. J Comp Neurol (2005) 485(4):304-20. doi:10.1002/cne.20497

48. Aihart MJ, Lee DH, Wilson TD, Miller BE, Miller MN, Skalko RG, et al. Adverse effects of serotonin depletion in developing zebrafish. Neurotoxicol Teratol (2012) 34(1):152-60. doi:10.1016/j.ntt.2011.08.008

49. Jannat $\mathrm{M}$, Sugiyono, Kishida $\mathrm{M}$. Nitrite $\left(\mathrm{NO}_{2}{ }^{-}\right)$perturbs the activitu of serotonergic neuron during early development of zebrafish. Int J Eng Res Sci Tech (2014) 3(4):1-11.

50. Norton WHJ. Measuring larval zebrafish behavior: locomotion, thigmotaxis, and startle. In: Kalueff AV, Stewart AM, editors. Zebrafish Protocols for Neurobehavioral Research. Totowa, NJ: Humana Press (2012). p. 3-19.

51. Brustein E, Chong M, Holmqvist B, Drapeau P. Serotonin patterns locomotor network activity in the developing zebrafish by modulating quiescent periods. J Neurobiol (2003) 57(3):303-22. doi:10.1002/neu.10292

52. Holzschuh J, Gimeno AB, Ettl AK, Dürr K, Knapik EW, Driever W. Noradrenergic neurons in the zebrafish hindbrain are induced by retinoic acid and require tfap2a for expression of the neurotransmitter phenotype. Development (2003) 130(23):5741-54. doi:10.1242/dev.00816

53. Wang Y, Takai R, Yoshioka H, Shirabe K. Characterization and expression of serotonin transporter genes in zebrafish. Tohoku JExp Med (2006) 208(3):267-74. doi:10.1620/tjem.208.267
54. Bashammakh S, Wurtele M, Kotnik K, Seyfried SA, Bader M. Serotonin is required for pharyngeal arch morphogenesis in zebrafish. ScienceOpen Res (2015):1-9. doi:10.14293/S2199-1006.1.SOR-LIFE.AWPDLZ.v1

55. Liu W, Chen C, Chen L, Wang L, Li J, Chen Y, et al. Sex-dependent effects of microcystin-LR on hypothalamic-pituitary-gonad axis and gametogenesis of adult zebrafish. Sci Rep (2016) 6:22819. doi:10.1038/srep22819

56. Caulier M, Brion F, Chadili E, Turies C, Piccini B, Porcher JM, et al. Localization of steroidogenic enzymes and Foxl2a in the gonads of mature zebrafish (Danio rerio). Comp Biochem Physiol A Mol Integr Physiol (2015) 188:96-106. doi:10.1016/j.cbpa.2015.06.016

57. Alharthy KM, Albaqami FF, Thornton C, Corrales J, Willett KL. Mechanistic evaluation of benzo[a]pyrene's developmental toxicities mediated by reduced cyp19alb activity. Toxicol Sci (2017) 155(1):135-47. doi:10.1093/toxsci/ $\mathrm{kfw} 182$

58. Vandenberg LN, Colborn T, Heyes TB, Heindel JJ, Jacobs DR, Lee D, et al. Hormones and endocrine-disrupting chemicals: low-dose effects and nonmonotonic dose responses. Endocr Rev (2012) 33(3):378-455. doi:10.1210/ er.2011-1050

59. Voss AK, Fortune JE. Estradiol-17- $\beta$ has a biphasic effect on oxytocin secretion by bovine granulosa cells. Biol Reprod (1993) 48:1404-9. doi:10.1095/ biolreprod48.6.1404

60. Sobel MI, Winkel CA, Macy LB, Liao P, Bjornsson TD. The regulation of plasminogen activators and plasminogen activator inhibitor type 1 in endothelial cells by sex hormones. Am J Obstet Gynecol (1995) 173:801-8. doi:10.1016/0002-9378(95)90344-5

61. Banerjee SK, Campbell DR, Weston AP, Banerjee DK. Biphasic estrogen response on bovine adrenal medulla capillary endothelial cell adhesion, proliferation and tube formation. Mol Cell Biochem (1997) 177:97-105. doi:10.1023/A:100688802

62. Weiss-Messer E, Ber R, Barkey RJ. Prolactin and MA-10 Leydig cell steroidogenesis: biphasic effects of prolactin and signal transduction. Endocrinology (1996) 137:5509-18. doi:10.1210/endo.137.12.8940378

63. Yokoyama K, Hayashi M, Mogi C, Sasakawa Y, Watanabe G, Taya K, et al. Dose-dependent effects of a glucocorticoid on protein production. Endocr $J$ (2008) 55(2):405-14. doi:10.1507/endocrj.K07E-063

64. Mazziotti G, Giustina A. Glucocorticoids and the regulation of growth hormone secretion. Nat Rev Endocrinol (2013) 9:265-76. doi:10.1038/nrendo. 2013.5

65. Zhang L, Yulong M, Qin P, Deng Y, Zhang Z, Hou Y, et al. The effects of various estrogen doses on the proliferation and differentiation of cultured neural stem cells. J Cell Sci Ther (2016) 7:247. doi:10.4172/2157-7013.1000247

66. Houshmand F, Faghihi M, Imani A, Kheiri S. Effect of different doses of oxytocin on cardiac electrophysiology and arrhythmias induced by ischemia. JAdv Pharm Technol Res (2017) 8(4):131-7. doi:10.4103/japtr.JAPTR_ $178 \_16$

67. Senthilkumaran B, Joy KP. Effects of ovariectomy and oestradiol replacement on hypothalamic serotonergic and monoamine oxidase activity in the catfish, Heteropneustes fossilis: a study correlating plasma oestradiol and gonadotrophin levels. J Endocrinol (1994) 142(2):193-203. doi:10.1677/joe.0. 1420193

68. Oliveira CA, Mehecha GAB, Carnes K, Prins GS, Saunders PTK, França L, et al. Differential hormonal regulation of estrogen receptors ER $\alpha$ and ER $\beta$ and androgen receptor expression in rat efferent ductules. Reproduction (2004) 128(1):73-86. doi:10.1530/rep.1.00136

69. McCarthy MM. Estradiol and the developing brain. Physiol Rev (2008) 88(1):91-134. doi:10.1152/physrev.00010.2007

70. Micevych PE, Mermelstein PG, Sinchak K. Estradiol membrane-initiated signaling in the brain mediates reproduction. Trends Neurosci (2017) 40(11): 654-66. doi:10.1016/j.tins.2017.09.001

71. Boulware MI, Mermelstein PG. Membrane estrogen receptors activate metabotropic glutamate receptors to influence nervous system physiology. Steroids (2009) 74(7):608-13. doi:10.1016/j.steroids.2008.11.013

72. Cover KK, Maeng LY, Lebrón-Milad K, Milad MR. Mechanisms of estradiol in fear circuitry: implications for sex differences in psychopathology. Transl Psychiatry (2014) 5(4):e422. doi:10.1038/tp.2014.67

73. Micevych PE, Kelly MJ. Membrane estrogen receptor regulation of hypothalamic function. Neuroendocrinology (2012) 96(2):103-10. doi:10.1159/ 000338400

74. Xu H, Qin S, Carassco GA, Dai Y, Filardo EJ, Prossnitz ER, et al. Extranuclear estrogen receptor GPR30 regulates serotonin function in rat hypo- 
thalamus. Neuroscience (2009) 158(4):1599-607. doi:10.1016/j.neuroscience. 2008.11.028

75. Teraoka H, Russell C, Regan J, Chandrasekhar A, Concha ML, Yokoyama R, et al. Hedgehog and Fgf signaling pathways regulate the development of tphRexpressing serotonergic raphe neurons in zebrafish embryos. J Neurobiol (2004) 60(3):275-88. doi:10.1002/neu.20023

76. Lillesaar C, Tannhäuser B, Stigloher C, Kremmer E, Bally-Cuif L. The serotonergic phenotype is acquired by converging genetic mechanisms within the zebrafish central nervous system. Dev Dyn (2007) 236(4):1072-84. doi:10.1002/ dvdy. 21095

77. Côté F, Thévenot E, Fligny C, Fromes Y, Darmon M, Ripoche MA, et al. Disruption of the nonneuronal tph1 gene demonstrates the importance of peripheral serotonin in cardiac function. Proc Natl Acad Sci U S A (2003) 100(23):13525-30. doi:10.1073/pnas.2233056100

78. Romano SN, Edwards HE, Sounder JP, Ryan KJ, Cui X, Gorelick DA. $G$ protein-coupled estrogen receptor regulates embryonic heart rate in zebrafish. PLoS Genet (2017) 13(10):e1007069. doi:10.1371/journal.pgen.1007069

79. Babiker FA, De Windt LJ, van Eickels M, Grohe C, Meyer R, Doevendans PA. Estrogenic hormone action in the heart: regulatory network and function. Cardiovasc Res (2002) 53(3):709-19. doi:10.1016/S0008-6363(01)00526-0

80. Bell JR, Mellor KM, Wollermann AC, Ip WT, Reichelt ME, Meachem SJ, et al. Aromatase deficiency confers paradoxical postischemic cardioprotection. Endocrinology (2011) 152(12):4937-47. doi:10.1210/en.2011-1212

81. Jazbutyte V, Stumpner J, Redel A, Lorenzen JM, Roewer N, Thum T, et al. Aromatase inhibition attenuates desflurane-induced preconditioning against acute myocardial infarction in male mouse heart in vivo. PLoS One (2012) 7(8):e42032. doi:10.1371/journal.pone.0042032

82. Connernet JJ, Spratt DI. Aromatase blockade is associated with increased mortality in acute illness in male mice. JEndocr Soc (2017) 1(9):1113-9. doi:10.1210/js.2017-00128

83. Chang X, Kobayashi T, Senthilkumaran B, Kobayashi-Kajura H, Sudhakumari CC, Nagahama Y. Two types of aromatase with different encoding genes, tissue distribution and developmental expression in Nile tilapia (Oreochromis niloticus). Gen Comp Endocrinol (2005) 141(2):101-15. doi:10.1016/j.ygcen. 2004.11.020

84. Choi JY, Park JG, Jeong HB, Lee YD, Takemura A, Kim SJ. Molecular cloning of cytochrome $\mathrm{P} 450$ aromatases in the protogynous wrasse, Halichoeres tenuispinis. Comp Biochem Physiol B Biochem Mol Biol (2005) 141(1):49-59. doi:10.1016/j.cbpc.2005.01.009

85. Matsuoka MP, van Nes S, Andersen $\varnothing$, Benfey TJ, Reith M. Real-time PCR analysis of ovary- and brain-type aromatase gene expression during Atlantic halibut (Hippoglossus hippoglossus) development. Comp Biochem Physiol B Biochem Mol Biol (2006) 144(1):128-35. doi:10.1016/j.cbpb.2006. 02.008

86. Zhang Y, Zhang W, Yang H, Zhou W, Hu C, Zhang L. Two cytochrome P450 aromatase genes in the hermaphrodite ricefield eel Monopterus albus: mRNA expression during ovarian development and sex change. J Endocrinol (2008) 199(2):317-31. doi:10.1677/JOE-08-0303

87. Liu H, Mu X, Gui L, Su M, Li H, Zhang G, et al. Characterization and gonadal expression of FOXL2 relative to Cyp19a genes in spotted scat Scatophagus argus. Gene (2015) 561(1):6-14. doi:10.1016/j.gene.2014.12.060

88. Walz N, Mühlberger A, Pauli P. A human open field test reveals thigmotaxis related to agoraphobic fear. Biol Psychiatry (2016) 80(5):390-7. doi:10.1016/j. biopsych.2015.12.016

89. Treit D, Fundytus M. Thigmotaxis as a test for anxiolytic activity in rats. Pharmacol Biochem Behav (1988) 31:959-62. doi:10.1016/0091-3057(88)90413-3

90. Prut L, Belzung C. The open field as a paradigm to measure the effects of drugs on anxiety-like behaviors: a review. Eur J Pharmacol (2003) 463:3-33. doi:10.1016/S0014-2999(03)01272-X

91. Schönrr SJ, Steenbergen PJ, Richardson MK, Champagne DL. Measuring thigmotaxis in larval zebrafish. Behav Brain Res (2012) 228(2):367-74. doi:10.1016/j.bbr.2011.12.016

92. Champagne DL, Hoefnagels CC, de Kloet RE, Richardson MK. Translating rodent behavioral repertoire to zebrafish (Danio rerio): relevance for stress research. Behav Brain Res (2010) 214(2):332-42. doi:10.1016/j.bbr.2010. 06.001

93. Gurtman CG, Morley KC, Li KM, Hunt GE, McGregor IS. Increased anxiety in rats after 3,4-methylenedioxymethamphetamine: association with serotonin depletion. Eur J Pharmacol (2002) 446(1-3):89-96. doi:10.1016/S00142999(02)01820-4

94. Argyropoulos SV, Hood SD, Adrover M, Bell CJ, Rich AS, Nash JR, et al. Tryptophan depletion reverses the therapeutic effect of selective serotonin reuptake inhibitors in social anxiety disorder. Biol Psychiatry (2004) 56(7):503-9. doi:10.1016/j.biopsych.2004.07.006

95. Jia M, Pittman J. Deficits in striatal dopamine and hippocampal serotonin following induction of anxiety/depressive-like behaviors by bisphenol A. Arch Neurosci (2014) 2(1):e18555. doi:10.5812/archneurosci. 18555

96. Gebauer DL, Pagnussat N, Piato AL, Schaefer IC, Bonan CD, Lara DR. Effects of anxiolytics in zebrafish: similarities and differences between benzodiazepines, buspirone and ethanol. Pharmacol Biochem Behav (2011) 99(3):480-6. doi:10.1016/j.pbb.2011.04.021

97. Maximino C, Puty B, Matos Oliveira KR, Herculano AM. Behavioral and neurochemical changes in the zebrafish leopard strain. Genes Brain Behav (2013) 12(5):576-82. doi:10.1111/gbb.12047

98. Martínez-Cerdeño V, Noctor SC, Kriegstein AR. Estradiol stimulates progenitor cell division in the ventricular and subventricular zones of the embryonic neocortex. Eur J Neurosci (2006) 24(12):3475-88. doi:10.1111/ j.1460-9568.2006.05239.x

99. Yague JG, Muñoz A, de Monasterio-Schrader P, Defelipe J, Garcia-Segura LM, Azcoitia I. Aromatase expression in the human temporal cortex. Neuroscience (2006) 138(2):389-401. doi:10.1016/j.neuroscience.2005.11.054

100. Liu X, Bolteus AJ, Balkin DM, Henschel O, Bordey A. GFAP-expressing cells in the postnatal subventricular zone display a unique glial phenotype intermediate between radial glia and astrocytes. Glia (2006) 54(5):394-410. doi:10.1002/glia.20392

101. Pellegrini E, Mouriec K, Anglade I, Menuet A, Le Page Y, Guegeun MM, et al. Identification of aromatase-positive radial glial cells as progenitor cells in the ventricular layer of the forebrain in zebrafish. J Comp Neurol (2007) 501(1):150-67. doi:10.1002/cne.21222

102. Djavadian RL. Serotonin and neurogenesis in the hippocampal dentate gyrus of adult mammals. Acta Neurobiol Exp (Wars) (2004) 64(2):189-200.

103. Norton WH, Folchert A, Bally-Cuif L. Comparative analysis of serotonin receptor (HTR1A/HTR1B families) and transporter (slc6a4a/b) gene expression in the zebrafish brain. JComp Neurol (2008) 511(4):521-42. doi:10.1002/cne.21831

104. Pérez MR, Pellegrini E, Nicolau JC, Gueguen MM, LeGuillou DM, Merot Y, et al. Relationships between radial glial progenitors and 5-HT neurons in the paraventricular organ of adult zebrafish-potential effects of serotonin on adult neurogenesis. Eur J Neurosci (2013) 38(9):3292-301. doi:10.1111/ ejn. 12348

105. Klempan T, Hudon-Thibeault AA, Oufkir T, Vaillancourt C, Sanderson JT. Stimulation of serotonergic 5-HT2A receptor signaling increases placental aromatase (CYP19) activity and expression in BeWo and JEG-3 human choriocarcinoma cells. Placenta (2011) 32(9):651-6. doi:10.1016/j.placenta.2011. 06.003

106. Xing L, Esau C, Trudeau VL. Direct regulation of aromatase b expression by $17 \beta$-estradiol and dopamine D1 receptor agonist in adult radial glial cells. Front Neurosci (2016) 9:504. doi:10.3389/fnins.2015.00504

Conflict of Interest Statement: The authors declare that there is no conflict of interest regarding the publication of this article.

Copyright $(0) 2018$ Ulhaq and Kishida. This is an open-access article distributed under the terms of the Creative Commons Attribution License (CC BY). The use, distribution or reproduction in other forums is permitted, provided the original author(s) and the copyright owner are credited and that the original publication in this journal is cited, in accordance with accepted academic practice. No use, distribution or reproduction is permitted which does not comply with these terms. 